\title{
UNCONDITIONAL SELF-ACCEPTANCE AND MENTAL HEALTH IN EGO-PROVOKING EXPERIMENTAL CONTEXT
}

\author{
Stanislava Popov \\ Medical High School \\ Novosadska 2, 23000 Zrenjanin, Serbia \\ stanislava.popov@gmail.com \\ Jelena Radanović \\ jelena.radanovic@uns.ac.rs \\ Mikloš Biro \\ Department of Psychology, Faculty of Philosophy \\ University of Novi Sad \\ Dr. Zorana Đinđića 2, 21000 Novi sad, Serbia \\ biro@ptt.rs
}

\begin{abstract}
Although it is one of the central concepts of Rational Emotive Behavioral Therapy (REBT), unconditional self-acceptance has not been sufficiently empirically examined, especially not experimentally. Therefore, the aim of this study was to examine the effects of unconditional self-acceptance on mental health indicators in an egoprovoking experimental situation. For a sample of 182 students, we simulated the situation of public speaking. After the simulation, participants were given previously prepared and randomly assigned positive, neutral and negative feedback. We used the Unconditional Self-Acceptance Questionnaire (USAQ: Chamberlain \& Haaga, 2001), Serbian Inventory of Affect based on PANAS-X (SIAB-PANAS: Novović \& Mihić, 2008), Anxiety subscale (DASS-42: Lovibond \& Lovibond, 1995), State Depression Scale (SD: Novović, Biro \& Nedimović, 2009) and Situational Attributional Style constructed for the purpose of this study (according to Peterson \& Seligman, 1984). Data were collected during the winter semester 2013/2014 at the University of Novi Sad. In the case of anxiety and depression as outcome variables (posttest measures), the analysis of covariance revealed a significant three-way interaction between the level of unconditional self-acceptance, the type of feedback and the satisfaction with feedback. On the other hand, the same predictors did not influence the measures of positive and negative affect. Various expectations from the feedback, as well as the feedback, provoke a certain self-assessment. Different pattern of effects in case of different outcome variables is in accordance with REBT theory.
\end{abstract}

Key words: unconditional self-acceptance, feedback, anxiety, depression 
In the focus of this study is the evaluative component of the Self, which is, almost always, associated with psychological problems - an excessively low or high evaluation of some aspects of the self is associated with different psychological disturbances (Chamberlain \& Haaga, 2001; David \& Szentagotai, 2008). The most investigated construct is self-esteem which represents general subjective, positive or negative, evaluation of the self (Sedikides \& Gregg, 2003). Self-esteem correlates with positive mental health indicators, psychological well-being and happiness (Diener \& Diener, 1995; DeNeve \& Cooper, 1998). Individuals with high self-esteem have lower levels of emotional distress (Sedikides, Rudich, Gregg, Kumashiro, \& Rusbult, 2004) and they are more likely to use adaptive stress coping strategies (Greenberg et al., 1992). On the other hand, people with low self-esteem have higher levels of psychological distress, depression and anxiety (Bernet, Ingram, \& Johnson, 1993; Tennen \& Affleck, 1993). Bearing in mind previous results, self-esteem could be seen as a "social vaccine" for preventing different personal problems in connection with social functioning. Many western countries implemented systematic programs for boosting self-esteem in education, health and business sectors (Baumeister, Campbell, Krueger, \& Vohs, 2003). However, there is little evidence for the efficacy of these programs (Baumeister et al., 2003). Also, there are several problems with current operationalization of self-esteem. Some studies suggest that self-esteem can't be reduced to high vs. low dichotomy (Sava, Maricutoiu, Rusu, Macsinga, \& Virga, 2011), and it is not an unidimensional construct (Kernis, 2005).

Rational Emotive Behavior Therapy (REBT) argues that self-evaluation of personality (positive or negative) and a general assessment of one's worth or value based on achieved performance, is irrational and leads to psychological problems. Most of the psychological disturbances associated with an excessive focus on selfesteem are mild, such as sensitivity to criticism, aggression, maladaptive perfectionism, etc. (as cited in Chamberlain \& Haaga, 2001), but there are those that are severely pathological (e.g. bipolar disorder) (O’Brien, Bartoletti, \& Leitzel, 2006). Therefore, the concept of self-esteem is detrimental to mental health, according to REBT. As a "healthier" substitute for self-esteem, REBT offers the concept of unconditional self-acceptance (Szentagotai \& David, 2013). Unconditional selfacceptance is defined as fully and unconditionally accepting yourself, regardless of whether you behave correctly, intelligently or competently, and regardless of whether people respect, accept or love you (Ellis, 1977). REBT sees unconditional self-acceptance as a continuum or as an intellectual and emotional habit which is expressed to a greater or lesser extent in different individuals. People with high unconditional self-acceptance are more resistant in ego-provoking situations such as failure or rejection (Chamberlain \& Haaga, 2001; Davies, 2006, 2007, 2008; Macinnes, 2006; Popov \& Popov, 2011).

We aimed at investigating the effects of the level of unconditional self-acceptance on several mental health variables (positive and negative affect, state anxiety and state depression) in the situation of a realistic stressor in the ego-threat 
domain. We used an experimental design which has rarely been used in the field and predicted that participants with lower levels of unconditional self-acceptance, dissatisfied with their feedback, would score higher for ego-disturbance symptoms (anxiety and depression) and negative affect compared to those with higher levels of unconditional self-acceptance. We also assumed that participants with higher levels of unconditional self-acceptance, satisfied with their feedback would score higher on positive affect.

\section{METHOD}

\section{Participants}

The sample consisted of 188 students ( $81 \%$ females) at the University of Novi Sad. We selected those study groups for which communication and presentation skills are an important part of their future profession. Psychology students were deliberately excluded because they are familiar with these kinds of experiments. After the elimination of multivariate outliers (according to the Mahalanobis distances; Tabachnick \& Fidell, 2001) 182 participants remained in the final sample. The mean age of the participants was 20.14 years $(S D=3.17)$.

\section{Instruments and variables}

The instruments used are described below.

Serbian Inventory of Affect based on the Positive and Negative Affect Schedule-X (SIAB-PANAS: Novović \& Mihić, 2008) is a Serbian translation and adaptation of the Positive and Negative Affect Schedule-X (PANAS-X: Watson \& Clark, 1994). A short version of the questionnaire, consisting of 20 items, was used to assess states of positive and negative affect (Positive Affect (PA) pre-test $\alpha=.91$, PA post-test $\alpha$ $=.93$, Negative Affect (NA) pre-test $\alpha=.85$, NA post-test $\alpha=.83$ )

Unconditional Self-Acceptance Questionnaire (USAQ: Chamberlain \& Haaga, 2001) is a Serbian translation of the original instrument (Chamberlain \& Haaga, 2001). USAQ consists of 20 statements with a 7- point Likert scale, that reflect various aspects of USA philosophy, as used in REBT (post-test $\alpha=.70$ ).

Anxiety Scale from Depression, Anxiety, Stress Scale (DASS-42: Lovibond \& Lovibond, 1995) assesses autonomic arousal, skeletal muscle effects, situational anxiety, and subjective experience of anxious affect. The scale contains 14 items with a 4-point Likert-type response format (pre-test $\alpha=.86$, post-test $\alpha=.85$ )

A State Depression Scale (SD: Novović, Biro, \& Nedimović, 2009) assesses the presence of depressive affect and its cognitive content, as well as other behavioral 
and motivational interferences in relation to a depressive state. The scale contains 20 items with 5-point Likert scale (pre-test $\alpha=.91$, post-test $\alpha=.91$ ).

The Situational Attributional Style Questionnaire (SASQ: Popov, 2014) was constructed for the purpose of this study. Beside attributional style, SASQ measures several variables including satisfaction with feedback, which is only relevant to this study. The respondents' task was to indicate to what extent they felt satisfaction with feedback on a 7-point Likert scale.

\section{Data collection procedure}

Considering the nature of the study, the experiment had to be blind, i.e. the information about the experiment was kept from the participants until after the experiment. Data were collected at the University of Novi Sad, during the winter semester 2012/2013 in several stages:

1. Students were informed that the University was introducing a new course: Public speaking skills. They were invited to voluntarily participate in establishing the criteria for the distribution of students at different levels of the course. Students participated in the study in exchange for course credits. The three-member "jury" was introduced to participants, whose alleged role was to judge participants' public speaking skills.

2. After the sample selection, we conducted the first testing session (pretest phase) in order to measure dependent (depression, anxiety, positive and negative affect) and moderator variables (unconditional self-acceptance, feedback and satisfaction with feedback) and to collect demographic data. These testing sessions, as well as other parts of the experiment, were conducted in groups of 15 participants on average.

3. Further, participants were given a short text about public speaking. Their task was to prepare themselves for an oral presentation in front of other colleagues and the "jury". They had 5 minutes to prepare the presentation.

4 Time allowed for the presentation was 1 minute and participants were interrupted after the time ran out. Participants were informed about limited time for the oral presentation in the previous phase.

5. After the presentations, participants were asked to leave the room for a few minutes until the "jury" created individual feedback information. Instead of that, the "jury" simply placed the feedback information in the envelope with the name and surname of the participants. There were an equal number of positive, negative and neutral feedbacks and they were randomly assigned to participants. Along with the envelopes, participants received a battery of instruments for posttest measuring of dependent variables.

6. At the end, the participants were debriefed and they received oral and written explanation of the whole procedure. 


\section{RESULTS}

The data were analyzed using the analysis of covariance. The effects of a set of factors (level of unconditional self-acceptance, type of feedback and satisfaction with the feedback) on different dependent variables were tested in separate analyses. Posttest measures of mental health indicators that served as dependent variables were: depression, anxiety, positive and negative affect while pretest measures of the same variables served as covariates. Unconditional self-acceptance scores and satisfaction with feedback were dichotomized by a median split prior to the analysis scores above the median represented high scores on reported measures while scores below the median were treated as low scores. The used factors were predictive for posttest measures of mental health indicators only for depression and anxiety; positive and negative affect remained unchanged by manipulating feedback. The effects from depression and anxiety ANCOVAs that reached statistical significance are presented in Table 1.

As can be seen in Figure 1, left graph, participants with lower scores on unconditional self-acceptance, who were less satisfied with positive feedback they

Table 1. The effects of unconditional self-acceptance, type of feedback and satisfaction with feedback on depression and anxiety

\begin{tabular}{|c|c|c|c|c|c|}
\hline & \multicolumn{2}{|c|}{ Anxiety } & & \multicolumn{2}{|c|}{ Depression } \\
\hline & $F$ & $p$ & & $F$ & $p$ \\
\hline SA_pre & 41.428 & .000 & SD_pre & 304.239 & .000 \\
\hline $\mathrm{USA} \times \mathrm{FS} \times \mathrm{FB}$ & 3.270 & .041 & $\mathrm{USA} \times \mathrm{FS} \times \mathrm{FB}$ & 5.584 & .005 \\
\hline
\end{tabular}

Note: USA-unconditional self-acceptance; SA_pre-state anxiety pretest; SD_pre-state depression pretest; FS-feedback satisfaction; FB-feedback
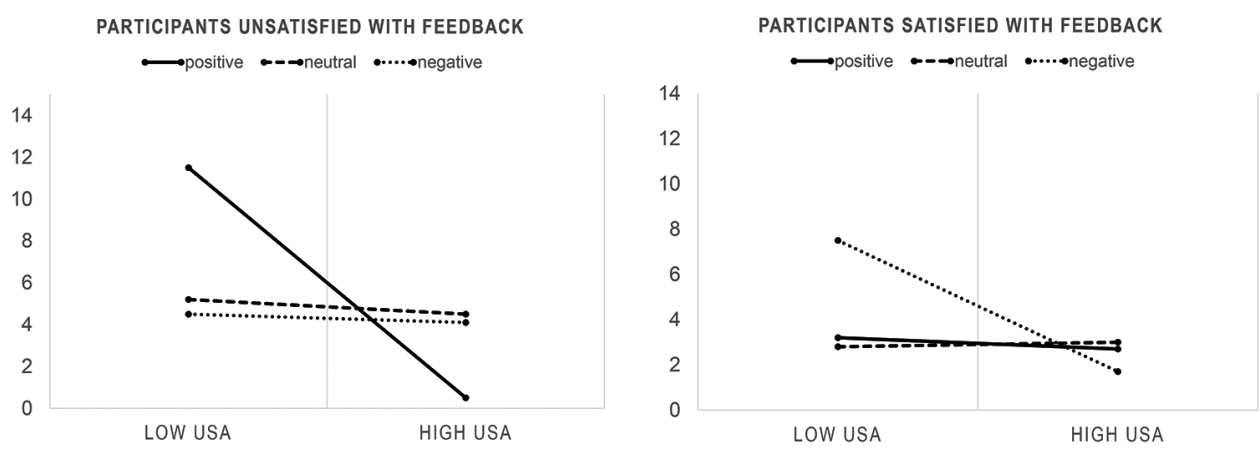

Figure 1. Effects of level of unconditional self-acceptance, type of feedback and satisfaction with feedback on posttest anxiety. 

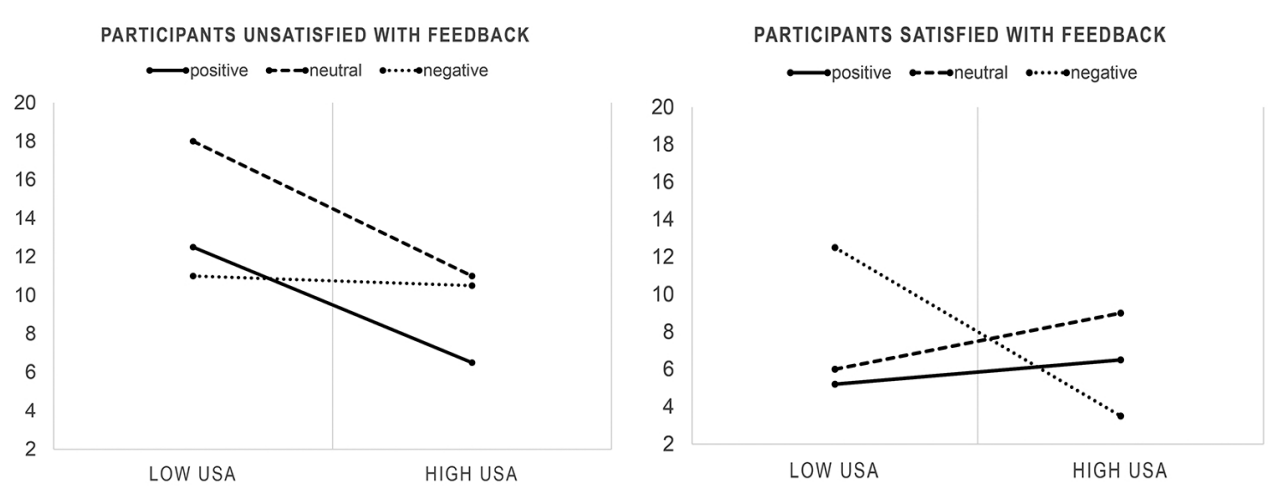

Figure 2. Effects of level of unconditional self-acceptance, type of a feedback and satisfaction with a feedback on posttest depression.

received, were more anxious in comparison with other participants. On the other hand, participants with lower unconditional self-acceptance but more satisfied with the feedback, were more anxious in case of a negative feedback than other participants (Figure 1, right graph).

With regards to depression, participants with lower unconditional self-acceptance dissatisfied with feedback were more depressive in comparison to those with higher unconditional self-acceptance both in case of neutral as well as positive feedback. At the same time, participants with lower unconditional self-acceptance who were satisfied with received feedback were more depressive in response to negative feedback in comparison to participants with higher unconditional selfacceptance.

\section{DISCUSSION}

Results presented here support predictions of REBT theory about the protective role of unconditional self-acceptance in depressive and anxious emotional reactions on stressful situations. Stressors were operationalized as feedback on public speaking, but we also examined the role of stressor evaluation - satisfaction with feedback. We hypothesised that unconditional self-acceptance would have different effects on mental health indicators for participants with different satisfaction with feedback, which is exactly what we obtained.

The participants with low unconditional self-acceptance who were not satisfied with feedback were more anxious and more depressive than the participants with higher unconditional self-acceptance, both after positive and neutral feedback. Participants with lower unconditional self-acceptance, but satisfied with negative feed- 
back, are more anxious than participants with higher unconditional self-acceptance. On the other hand, participants with lower unconditional self-acceptance who are not satisfied with feedback are the most anxious in case of positive feedback. The lowest score on the depression scale was after negative feedback. It seems like these participants do not accept negative feedback, so it does not influence their depressive symptoms. On the other hand, when someone is satisfied with the feedback, lower unconditional self-acceptance means higher scores on a depression scale. This pattern of results might mean that these participants expected negative feedback and since they are prone to self-deprecation they had a higher score on the depression scale. Similar unconditional self-acceptance moderation of the relationship between type of feedback and satisfaction with it, on the one hand, and mental health variable on the other hand, is obtained in the case of anxiety. The reason could be pessimistic attribution where negative events are interpreted with the internal, stable and pervasive cause (Peterson \& Seligman, 1984). However, this is a hypothesis wich should be examined.

Overall, these results indicate that personal interpretation of events, more than the events themself, is more important for quality of emotional response. It is confirmation for one of the fundamental ideas underlying REBT: "People are not disturbed by things, but by the view they take of them" (Epictetus as cited in Ellis, 1977) and it is crucial for the therapeutic process.

Although the trend of the results are is as expected, the tested predictors did not reach statistical significance in the case of affectivity variables. We assume that this might happen because the emotional response in the present experimental situation is not necessarily dysfunctional. Namely, REBT makes differences between healthy and unhealthy negative emotions which differ qualitatively more than quantitatively (Dryden, 2002). According to REBT, healthy positive and negative emotions should be less influenced by interaction of self-evaluation, feedback and satisfaction with it. It is unclear how much the variance of affect, measured in this study, is saturated with (un)healthy emotional responses because the instrument that we used is not designed to distinguish healthy and unhealthy emotional response. For future research in the context of REBT it would be useful to construct an instrument that would discriminate between healthy (functional) and unhealthy (dysfunctional) emotions.

Although the complex joint effect of the level of unconditional self-acceptance, type of feedback and satisfaction with it on clinically relevant variables presented here cannot be taken as sufficient evidence for therapeutical usefullness of unconditional self-acceptance, it certainly does qualify unconditional self-acceptance for the "race" with other self-evaluative constructs in predicting mental health variables. Therefore, the work on the "psychological reality" of unconditional self-acceptance should be continued in the same direction - investigating the effects of unconditional self-acceptance in other controlled but ecologically valid settings. 


\section{REFERENCES}

Baumeister, R. F., Campbell, J. D., Krueger, J. I., \& Vohs, K. D. (2003). Does high selfesteem cause better performance, interpersonal success, happiness, or healthier lifestyles? Psychological Science in the Public Interest, 4(1), 1-44.

Bernet, C. Z., Ingram, R. E., \& Johnson, B. R. (1993). Self-esteem. In C. Costello (Ed.), Symptoms of depression (pp. 141-159). New York: Wiley.

Chamberlain, J. M., \& Haaga, D. A. F. (2001). Unconditional self-acceptance and psychological health. Journal of Rational-Emotive and Cognitive-Behavior Therapy, 19, $163-$ 176.

David, D., \& Szentagotai, A. (2008). The "Self" in REBT: Between self-esteem and unconditional self-acceptance. Retrieved from http:/www.rebt.org/professionals/pdf_files/ aei_ac.pdf

Davies, M. F. (2006). Irrational beliefs and unconditional self-acceptance. I. Correlational evidence linking two key features of REBT. Journal of Rational-Emotive and Cognitive Behavior Therapy, 24, 113-124.

Davies, M. F. (2007). Irrational beliefs and unconditional self-acceptance. II. Experimental evidence for a causal link between two key features of REBT. Journal of Rational-Emotive \& Cognitive-Behavior Therapy, 26, 89-101.

Davies, M. F. (2008). Irrational beliefs and unconditional self-acceptance. III. The relative importance of different types of irrational belief. Journal of Rational-Emotive \& Cognitive-Behavior Therapy, 26, 102-118.

DeNeve, K. M., \& Cooper, H. (1998). The happy personality: A meta-analysis of 137 personality traits and subjective well-being. Psychological Bulletin, 124, 197-229.

Diener, E., \& Diener, M. (1995). Cross-cultural correlates of life satisfaction and selfesteem. Journal of Personality and Social Psychology, 68, 653-663.

Dryden, W. (2002). Fundamentals of Rational Emotive Behaviour Therapy: A training manual. New York: John Wiley \& Sons.

Ellis, A. (1977). Psychotherapy and the value of human being. In A. Ellis \& R. Grieger (Eds.), Handbook of rational-emotive therapy (pp. 99-112). New York: Springer.

Greenberg, J., Solomon, S., Pyszczynski, T., Rosenblatt, A., Burling, J., Lyon, D., ... Pinel, E. (1992). Why do people need self-esteem? Converging evidence that self-esteem serves an anxiety-buffering function. Journal of Personality and Social Psychology, 63, 913-922.

Kernis, M. H. (2005). Measuring self-esteem in context: The importance of stability of selfesteem in psychological functioning. Journal of Personality, 73, 1569-1605.

Lovibond, P. F., \& Lovibond, S. H. (1995). The structure of negative emotional states: Comparison of the Depression Anxiety Stress Scales (DASS) with the Beck Depression and Anxiety Inventories. Behaviour Research and Therapy, 33, 335-343.

Macinnes, D. L. (2006). Self-esteem and self-acceptance: An examination into their relationship and their effect on psychological health. Journal of Psychiatric and Mental Health Nursing, 13, 483-489.

Novovic, Z., \& Mihic, Lj. (2008). Serbian Inventory of Affect based on the Positive and Negative Affect Schedule-X. Unpublished manuscript, University of Novi Sad, Serbia. 
Novović, Z., Biro, M., \& Nedimović, T. (2009). Procena stanja depresivnosti [Assessment of depression state]. In M. Biro, S. Smederevac, \& Z. Novović (Ed.), Procena psiholoških i psihopatoloških fenomena (pp. 19-28). Beograd: Centar za primenjenu psihologiju.

O’Brien, E. J., Bartoletti, M., \& Leitzel, J. D. (2006). Self-esteem, psychopathology, and psychotherapy. In M. Kernis (Ed.), Self-esteem issues and answers: A sourcebook of current perspectives (pp. 306-315). New York, NY: Psychology Press.

Peterson, C., \& Seligman, M. E. (1984). Causal explanations as a risk factor for depression: Theory and evidence. Psychological Review, 91, 347-374.

Popov, S. (2014). Validation of unconditional self-acceptance construct and its relation to implicit and explicit self-esteem (Unpublished doctoral dissertation). University of Novi Sad, Serbia.

Popov, S., \& Popov, B. (2011). Unconditional self-acceptance as a correlate of adolescent mental health. Paper presented at the International scientific conference $20^{\text {th }}$ Ramiro and Zoran Bujas' Days. Faculty of Humanities and Social Sciences, University of Zagreb, Croatia.

Sava, F. A., Maricutoiu, L. P., Rusu, S., Macsinga, I., \& Virga, D. (2011). Implicit and explicit self-esteem and irrational beliefs. Journal of Cognitive Behavioral Psychotherapies, 11, 97-111.

Sedikides, C., \& Gregg, A. P. (2003). Portraits of the self. In M. A. Hogg \& J. Cooper (Eds.), Sage handbook of social psychology (pp. 110-138). London: Sage.

Sedikides, C., Rudich, E. A., Gregg, A. P., Kumashiro, M., \& Rusbult, C. (2004). Are normal narcissists psychologically healthy? Self-esteem matters. Journal of Personality and Social Psychology, 87, 400-416.

Szentagotai, A., \& David, D. (2013). Self-acceptance and happiness. In M. Bernard (Ed.), The strength of self-acceptance: Theory, practice and research (pp. 121-139). New York: Springer.

Tabachnick, B. G., \& Fidell, L. S. (2001). Using multivariate statistics. Boston: Allyn and Bacon.

Tennen, H., \& Affleck, G. (1993). The puzzles of self-esteem: A clinical perspective. In R. F. Baumeister (Ed.), Plenum series in social/clinical psychology (pp. 241-262). New York: Plenum Press.

Watson, D., \& Clark, L.A. (1994). The PANAS-X: Manual for the positive and negative affect schedule-expanded form. Unpublished manuscript. 


\title{
BEZUVJETNO SAMOPRIHVAĆANJE I MENTALNO ZDRAVLJE U EKSPERIMENTALNOM EGO -PROVOCIRAJUĆEM KONTEKSTU
}

\begin{abstract}
Sažetak
Iako je jedan od središnjih koncepata Racionalno Emotivno Bihevioralne Terapije (REBT), koncept bezuvjetnog samoprihvaćanja nije dovoljno empirijski istraživan, naročito ne eksperimentalno. Zato je cilj ovog istraživanja je ispitivanje utjecaja bezuvjetnog samoprihvaćanja na pokazatelje mentalnog zdravlja u eksperimentalnoj ego- provocirajućoj situaciji. Na uzorku od 182 studenta, simulirali smo situaciju javnog nastupa za koji su ispitanici dobili unaprijed pripremljeni, slučajno raspoređeni pozitivni, neutralni i negativni feedback te smo ispitivali efekte interakcije bezuvjetnog samoprihvaćanja, feedbacka i zadovoljstva dobivenim feedbackom na pokazatelje mentalnog zdravlja. Korišteni mjerni instrumenti su: Skala bezuvjetnog samoprihvaćanja (USAQ; Chamberlain \& Haaga, 2001), Srpski inventar afekata baziran na PANAS-X (SIAB- PANAS; Novović \& Mihić, 2008), Subskala anksioznosti (DASS-42; Lovibond \& Lovibond, 1995), Skala stanja depresivnosti (SD; Novović, Biro \& Nedimović, 2009) i Skala situacionog atribucijskog stila konstruirana za ovo istraživanje (prema Peterson \& Seligman, 1984). Podaci su prikupljeni tijekom zimskog semestra 2013/2014 godine na Sveučilištu u Novom Sadu. Rezultati analize kovarijanse ukazuju na to da razina samoprihvaćanja ima veću ulogu u predikciji anksioznosti i depresivnosti $\mathrm{u}$ interakciji sa zadovoljstvom dobivenim feedbackom od same prirode feedbacka. S druge strane, isti prediktori nisu utjecali na mere pozitivnog i negativnog afekta. Različita očekivanja od dobivenog feedbacka, kao i sam feedback, provociraju određenu samoprocjenu, te se različite kombinacije ovih faktora na drugačiji način reflektiraju na pokazatelje mentalnog zdravlja, sukladno sa REBT teorijom.
\end{abstract}

Ključne riječi: bezuvjetno samoprihvaćanje, feedback, anksioznost, depresivnost

Prihvaćeno za tisak: 07. 09. 2016. 